\title{
LATE OLIGOCENE LARGER FORAMINIFERA FROM NOSARA (NICOYA PENÍNSULA, COSTA RICA) AND INDWARD (CARRIACOU, LESSER ANTILLES), CALIBRATED BY ${ }^{87} \mathrm{SR} /{ }^{86} \mathrm{SR}$ ISOTOPE STRATIGRAPHY
}

\author{
Claudia Baumgartner-Mora*, Peter O. Baumgartner \& Pascal Tschudin \\ Institut de Géologie et Paléontologie, Anthropole, \\ Université de Lausanne, 1015 Lausanne, Switzerland. \\ *Autor para contacto: Claudia.Baumgartner@unil.ch
}

(Recibido, 24/03/07; aceptado: 03/10/07)

\begin{abstract}
The Late Oligocene first occurrence of Miogypsina gunteri Cole and Miogypsina tani Drooger is verified in the light of larger foraminiferal assemblages from Nosara (Nicoya Peninsula, Costa Rica) and Windward (Carriacou, Grenada, Lesser Antilles). At Windward, they co-occur with planktonic foraminifera and nannofossils studied by earlier workers. $87 \mathrm{Sr} / 86 \mathrm{Sr}$ isotope ratios were measured in calcite of larger foraminifera at both sites to determine independent absolute ages of the two outcrops.

Late Oligocene shallow water formations unconformably overlie Paleocene-Eocene distal turbidites and siliceous shales in the outcrops in Costa Rica. The shallow-water lithostratigraphy includes near shore volcanic sandstones that alternate with sandy bioclastic limestones. The latter have yielded rich assemblages of larger foraminifera that have been studied in oriented sections, SEM for split material and polished rock thin sections for transmitted light and cathodoluminescence (CL) observation. The association of larger foraminifera includes Heterostegina antillea Cushman, Miogypsina tani Drooger, Miogypsina gunteri Cole, Miogypsina c.f (Miolepidocyclina) panamensis (Cushman), Miogypsina sp., Lepidocyclina (nephrolepidina) vaughani Cushman, Lepidocyclina yurnagurensis Cushman, Lepidocyclina undosa Cushman.

At Windward, scattered outcrops of the Belvedere Formation expose mass flow deposits rich in larger foraminifera associated with an early late Oligocene (NP24) planktonic foraminifa assemblage. Planktonic foraminifera and nannofossils recovered in rocks slightly downsection indicate an upper Middle Oligocene age. Larger foraminifera species collected just north of Windward include Lepidocyclina undosa Cushman and Miogypsina gunteri Cole.

The ${ }^{87} \mathrm{Sr} /{ }^{86} \mathrm{Sr}$ ratio was measured in 11 specimens of megalosphaeric Lepidocyclina spp., mechanically extracted from 2 rock samples collected at Punta Peladas (Costa Rica) Ratios range from 0.709088 to 0.708196 , which correspond to a model age of 27.4 to $24.94 \mathrm{Ma}$. Very similar ratios, ranging from 0.708150 to 0.708167 were obtained from Windward
\end{abstract}


Village (Carriacou). All measured $87 \mathrm{Sr} / 86 \mathrm{Sr}$ ratios fall within a Chattian (Late Oligocene) age. Nannofossils, planktonic foraminifera and identical ${ }^{87} \mathrm{Sr} /{ }^{86} \mathrm{Sr}$ ratios from Punta Peladas and Windward clearly indicate a Chattian (Upper Oligocene) first occurrence of Miogypsina gunteri and Miogypsina tani and confirm this age range for the other larger foraminifera cited above. The first occurrence of Miogypsina gunteri in the lower Aquitanian and Miogypsina tani in the upper Aquitanian as proposed by European workers cannot be confirmed.

Key words: Larger foraminifera, Miogypsina, Oligocene, Costa Rica, Carriacou, strontium isotope ratios.

RESUMEN: La presencia del género Miogypsina en las localidades de Nosara en la Peninsula de Nicoya (Costa Rica) y de Windward en la isla de Carriacou, (Granada, Antillas Menores) en el Oligoceno Superior se confirma en el presente trabajo. En la localidad de Windward, los macroforamíniferos se encuentran asociados con foraminíferos planctónicos y con nanofósiles. En ambas localidades se procedió al análisis de la proporción de los isótopos ambientales ${ }^{87} \mathrm{Sr} /{ }^{86} \mathrm{Sr}$. Los análisis de estroncio nos permiten determinar la edad absoluta de los macroforaminíferos en ambas localidades. En los afloramientos costeros en Costa Rica, las secuencias sedimentarias de aguas someras de edad Oligoceno Superior, sobreyacen discordantemente las turbiditas distales y lutitas silíceas del Paleoceno-Eoceno. La secuencia de sedimentos incluye areniscas volcánicas someras alternantes con calizas bioclásticas. Las calizas son ricas en macroforaminíferos, los cuales se han extraído para cortes orientados y para el estudio en microscoscopio electrónico de barrido (SEM). La mayor parte de las muestras han sido estudiadas en secciones delgadas pulidas para cátodo-luminescencia (CL) combinada con luz transmitida. La asociación de macroforaminíferos incluye: Heterostegina antillea Cushman, Miogypsina tani Drooger, Miogypsina gunteri Cole, Miogypsina (Miolepidocyclina) sp., Miogypsina sp., Lepidocyclina (nephrolepidina) vaughani Cushman, Lepidocyclina yurnagurensis Cushman, Lepidocyclina undosa Cushman.

En Windward, los afloramientos de la Formación Belvedere exponen depósitos de flujos en masa ricos en macroforaminíferos asociados con foraminíferos planctónicos del Oligoceno Superior (NP24). En rocas al sur de Windward los foraminíferos planctónicos y los nanofósiles indican una edad de Oligoceno Medio. Los macroforaminíferos recolectados en los afloramientos costeros al norte de Windward incluyen Lepidocyclina undosa Cushman y Miogypsina gunteri Cole. La razón ${ }^{87} \mathrm{Sr} /{ }^{86} \mathrm{Sr}$ fue medida en 11 especímenes megalosféricos de Lepidocyclina spp., recolectados en la sección de Punta Peladas (Costa Rica). Varía entre 0,709088 y 0,708196, lo cual corresponde a una edad de 27,4 a 24,94 Ma. Resultados muy similares en el porcentaje de ${ }^{87} \mathrm{Sr} /{ }^{86} \mathrm{Sr}$ fueron obtenidos en los especímenes de Windward. Todos los porcentajes indican una edad de Chatiano (Oligoceno Superior). El estudio de nanofósiles, foraminíferos planctónicos y los análisis de estroncio en Punta Peladas y en Windward, indican claramente una edad de Chatiano (Oligoceno Superior) para la primera ocurrencia de Miogypsina gunteri y Miogypsina tani. La primera aparición de Miogypsina gunteri en la base del Aquitaniano y de Miogypsina tani en el Aquitaniano superior, como fue propuesta por paleontólogos europeos, no se ha podido confirmar.

Palabras clave: Macroforaminíferos, Miogypsina, Oligoceno, Costa Rica, Carriacou, razón de isótopos de estroncio.

\section{INTRODUCTION}

The first occurrence of Miogypsina gunteri Cole and Miogypsina tani Drooger has been placed in the lower Miocene by European specialists (e.g., Butterlin, 1981; Adams, 1983), whereas these forms were classically described in the Americas from the middle - late Oligocene (Cole, 1938; Drooger, 1952). The examination of the means of correlation that led to these age calls, reveals considerable uncertainties and circular reasoning.

To solve this discrepancy, we examined two occurrences of larger foraminiferal assemblages from two distant places in the Caribbean Plate (Fig. 1): Punta Peladas, Nosara, located along the southeastern Pacific coast of the Nicoya Peninsula (Fig. 2) and Windward, located along the western coast of Carriacou (Grenada, Lesser Antilles) facing the Atlantic (Baumgartner-Mora et al., 2005). While the two sites show very similar assemblages of larger foraminifera, they differ in their sedimentary environment. The limestones at Nosara represent a shallow, open marine carbonate bank, whereas the carbonate beds of the Belvedere Formation exposed along the coast and in the village of Windward are mass flow deposits of shallow water material emplaced into a deep water paleoenvironment. This situation allowed the study of associated nannofloras (Speed et al., 1993) and planktonic foraminifera (Robinson \& Jung, 1972) that give a minimum age for the displaced larger foraminifera.

We will describe the lithology and sedimentology of the two sites, with higher emphasis to 


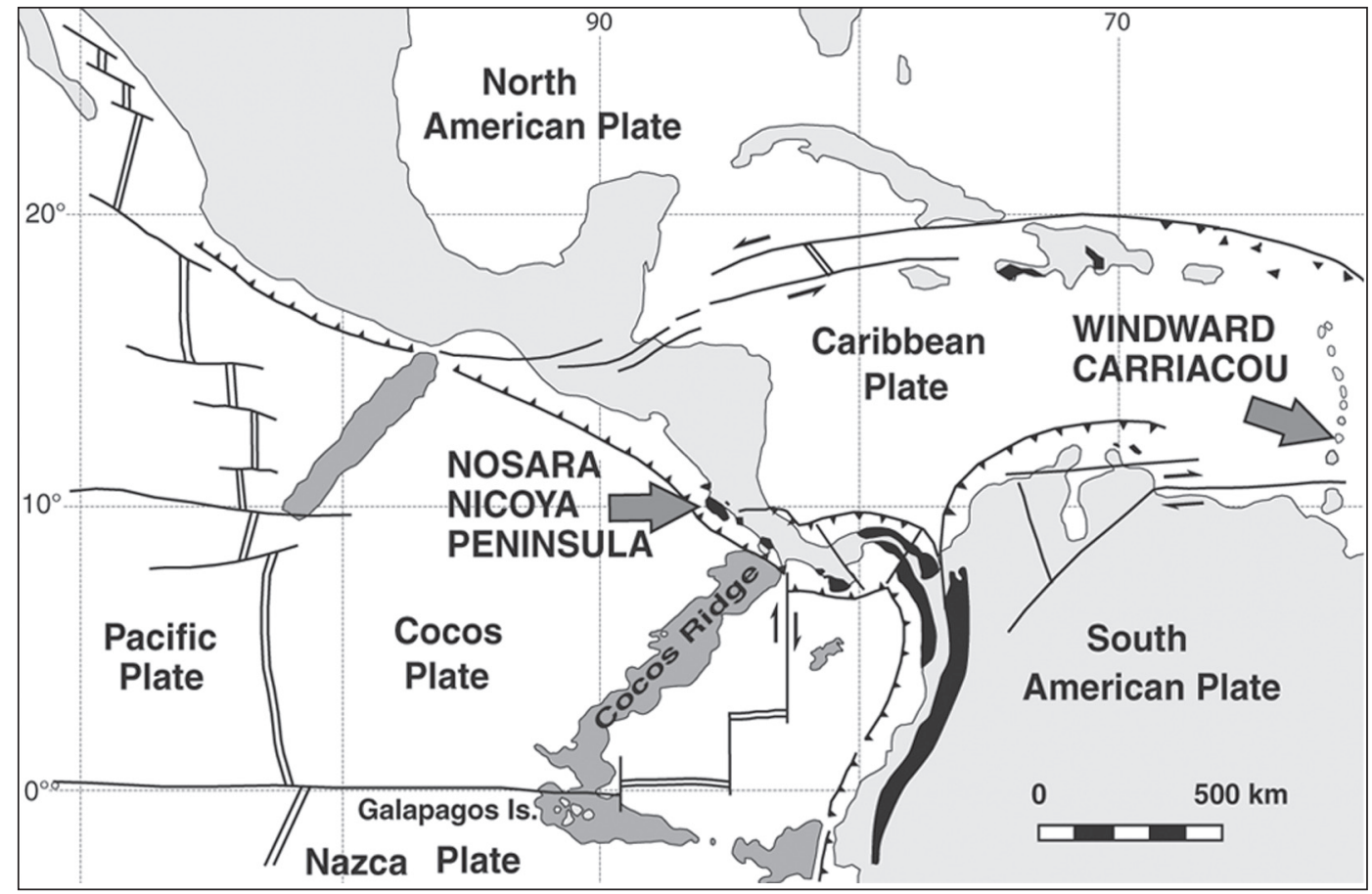

Fig. 1: Plate tectonic situation of Central America and the Caribbean with the location of the two localities Nosara and Windward. The ridges and seamounts are shown in dark gray; the mafic complexes of oceanic origin are in black.

the outcrops between Punta Peladas and Nosara river (Nicoya, Costa Rica) since less data on sedimentology have been published for this area. We will also describe the procedures for the measurement of Sr-isotope ratios in the test of larger foraminifera and their calibration with the relative and the absolute time scale. We finally will discuss the correlation of the observed larger foraminiferal assemblages with the planktonic foraminiferal zones.

\section{Previous work in Nosara (Costa Rica)}

Dengo (1962) originally described the limestone and sandstone outcrops between Punta Peladas and Punta Nosara (Nicoya Peninsula) as a correlative of the Nicaraguan Masachapa deepwater formation. Baumgartner et al. (1984) provided arguments for a shallow-water origin of the succession and compared it with shallow-water conglomerates and sandstones of Santa Teresa, further south in the Nicoya Peninsula (Fig.2). The name Punta Peladas has been used as a formation name in the stratigraphic nomenclature of Costa Rica in various ways by Sprechmann (1984) and Aguilar (1999) that will not be discussed here.

Few illustrated reports exist of larger foraminifera in Costa Rica. Malavassi (1961) published a report of larger foraminifera, unfortunately without any illustrations. He correlated the outcrops of Punta Peladas discussed here with the late Oligocene portion of the Caimito and Bohío formations of Panama (Cole, 1952).

The Costa Rican specimen of Miogypsina tani, from a sample collected from "Oligocene" outcrops of a fossiliferous conglomerate along the Reventazón river (Caribbean slope of the volcanic range) was illustrated by Drooger (1952) and Cole (1961).

\section{Previous work in Carriacou}

Carriacou is an emergent portion of the Lesser Antilles Arc Platform (Speed et al., 1993), which 


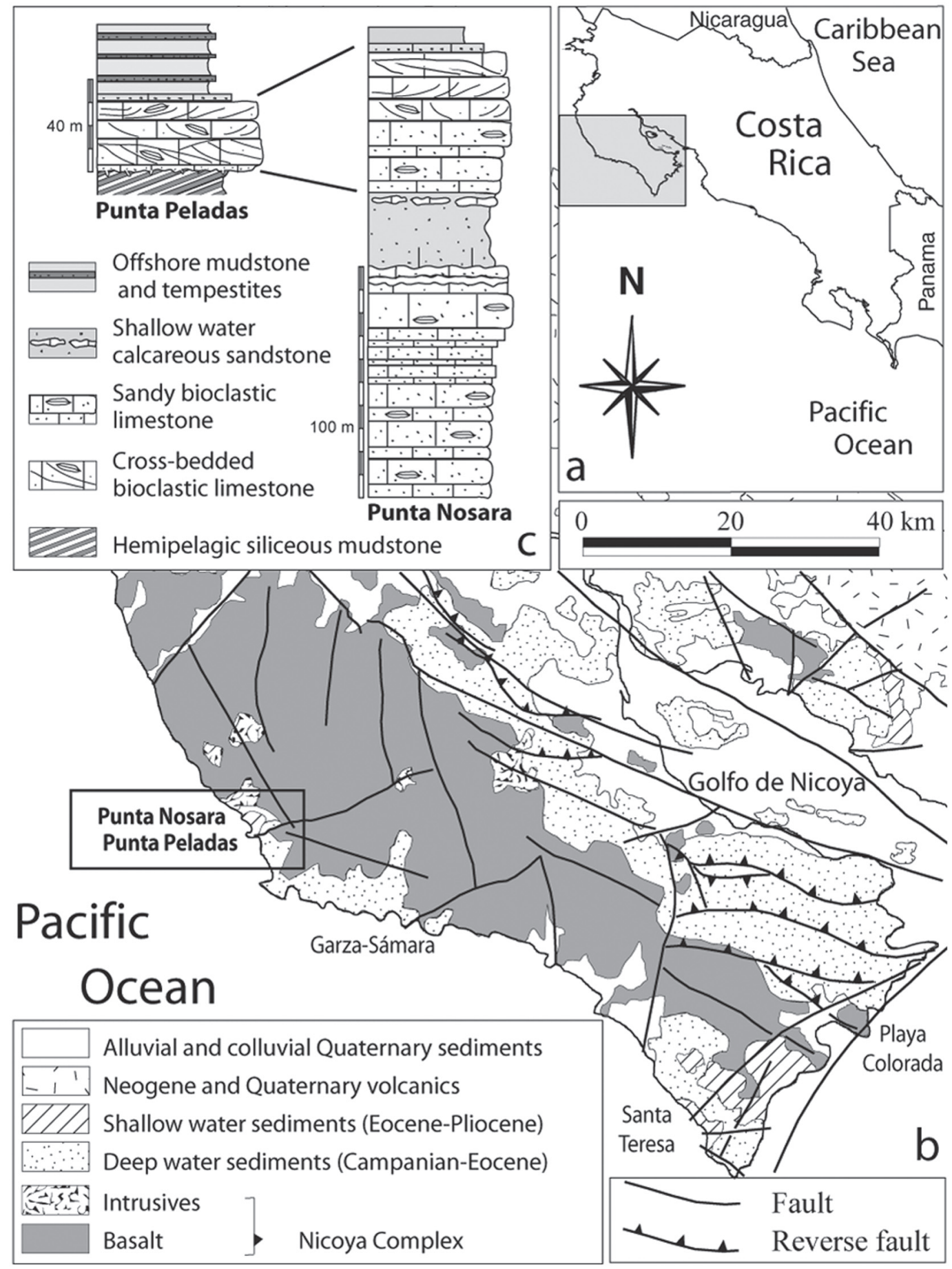

Fig. 2: a. General study area in the NW of Costa Rica. b. The studied sections are located along the central Pacific coast of the Nicoya Peninsula near the village of Nosara. c. Stratigraphic columns at Punta Peladas and Punta Nosara. At Punta Peladas, shallow water limestones rest on an angular unconformity cut into deep water siliceous mudstones that form an upthrown fault block. The shallow water limestones are overlain by off-shore tempestites. At Punta Nosara, neither the base nor the top of the section are visible. The tentative correlation of limestones between the two sections is based on facies comparison. 
oldest known rocks, basalts described and dated by Speed et al. (1993), were formed in the middle Eocene. They represent an oceanic basement of a deepwater sequence bottomed by pelagic limestones (Boogles Limestone, Fig. 3), and overlain by the Belvedere Formation discussed in this paper (Fig. 3).

The sedimentary rocks of Carriacou were mapped, dated and assigned to formational units by Lehner (1935), Martin-Kaye (1958), Westercamp et al. (1985) and Speed et al. (1993). Robinson \& Jung (1972) dated the Eocene to Miocene Formations by means of larger foraminifera. These authors assigned the Windward section discussed here to the "Windward Limestone and Tuffs" and dated the section as middle to late Oligocene (see below). The outcrops around Windward were included by Speed et al. (1993) with their newly defined Belvedere Formation.

\section{NOSARA (COSTA RICA): LITHOSTRATIGRAPHY, SEDIMENTOLOGY AND LARGER FORAMINIFERA}

\section{Lithostratigraphy and sedimentology}

Upper Oligocene shallow water formations unconformably overlie Paleocene-Eocene distal turbidites and siliceous shales in the outcrops between Punta Peladas and the Nosara river mouth, on the west coast of the Nicoya Peninsula (Costa Rica). This unconformity is very well exposed on the north facing cliffs of Punta Peladas (Pl. 1- 1). Here, bioclastic limestones rest on a flat, bored surface described below.

Dm-bedded pelagic to hemipelagic siliceous mudstones and cherts and distal volcanic and calcareous turbidites form the substrate of the unconformity. These rocks were intensely tectonized by synsedimentary stiff-sediment fracturing, then lithified, tilted landwards and uplifted to sea level, where they became levelled and bored in an infralittoral (intertidal) environment. The borings cut invariably across cherty and tuffaceous rocks. They are oblique, straight or curved, up to $10 \mathrm{~cm}$ deep and 1-2 $\mathrm{cm}$ thick. In part, they could be Pholas or Lithophaga borings. The bored cavity is filled with the shallow water lithology that encroaches on the unconformity, namely the bioclastic limestones of Punta Peladas.

At Punta Peladas, only estimated 25-30 m of bioclastic limestone rest on the unconformity and are conformably overlain by off-shore mudstones and tempestites (Baumgartner et al., 1984). In contrast, at the Nosara river mouth, we measured a $200 \mathrm{~m}$ section of interbedded limestones and volcanic sandstones, that neither shows the basal unconformity nor the tempestites on top. By facies analogy, we can correlate the topmost limestone level with Punta Peladas. If so, the basal unconformity must lie at a much deeper level and was probably subsiding during sedimentation in an active, graben-like structure to accommodate a roughly 10 times thicker shallow water sequence at the Nosara river mouth. The shallow water lithostratigraphy is described in detail below.

\section{Calcareous volcanic sandstones}

Calcareous mud-rich volcanic sandstones of 10-50 m thickness alternate with bioclastic limestones described below. The sandstones are massive, show little internal sedimentary structures and only crop out along the shore. Their passage to the limestone intervals is gradual. Lithologic differencies are enhanced by the early diagenesis of the limestones that makes them more resistant to weathering and hence forms cliffs along the shore and hills inland.

\section{Bioclastic limestones}

At Punta Peladas and around Punta Nosara, the coastal outcrops show well-bedded sandy bioclastic limestones up to $40 \mathrm{~m}$ thick. Bedding at a larger scale appears as metric, but the coastal erosion reveals that each metric bed is composed of bundles of dm-thick, often nodular beds that are separated by more argillaceous/tuffaceous, often deeply eroded interbeds. These bundles represent foresets that are often at up to $30^{\circ}$ angle with the base of the bundles. Individual sets of bundles are 


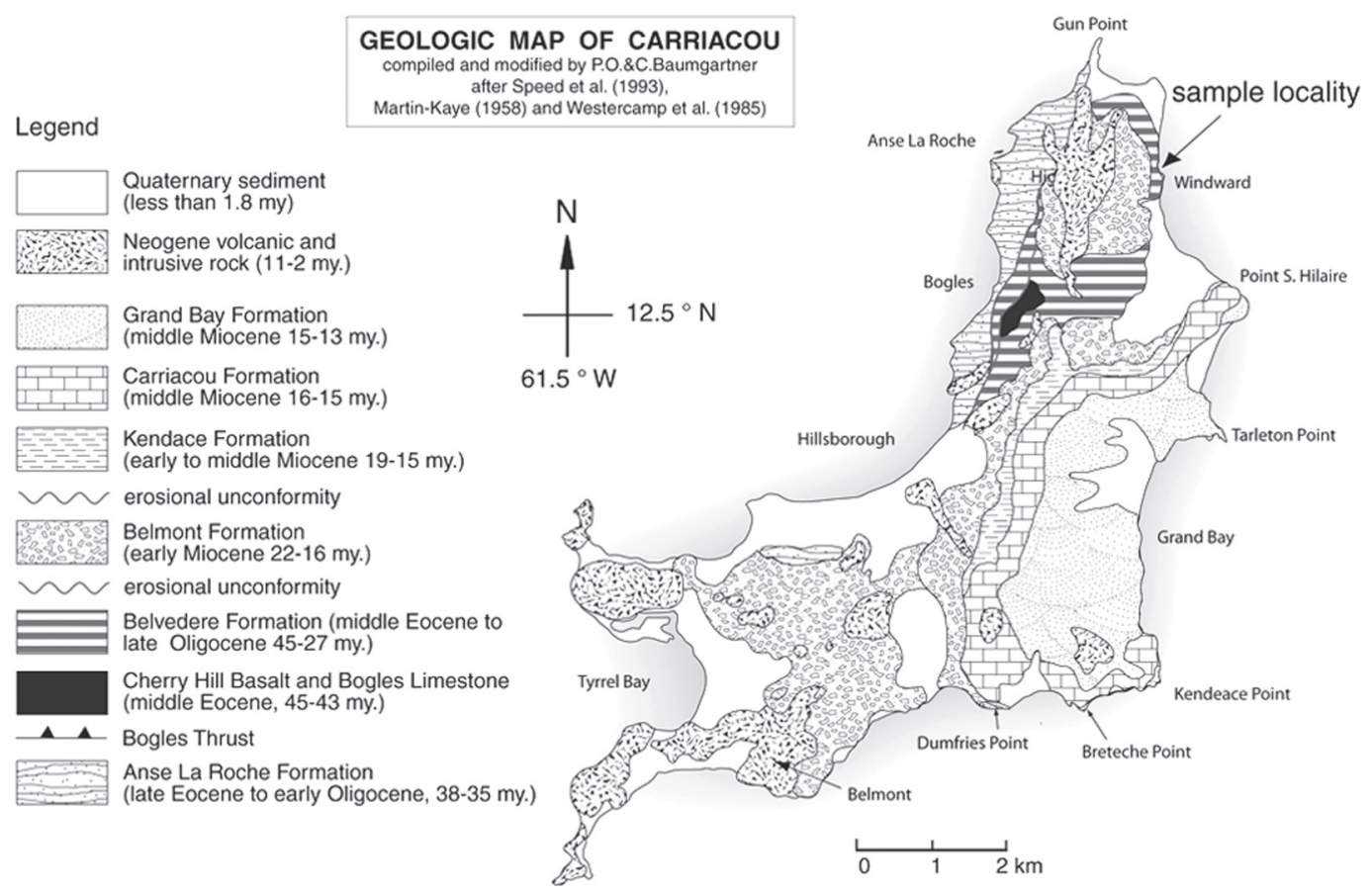

Fig. 3: Simplified geologic map of Carriacou Island (Grenada, Lesser Antilles). Compiled after Speed et al. (1993), Martin-Kaye (1958) and Westercamp et al. (1985) and completed by our own observations. The studied outcrops represent the youngest portions of the Belvedere Formation.

laterally discontinuous (Pl. 1- 3), pinch out and are replaced by other sets. In some places, dm-thick beds appear as slumped locally and truncated upsection by erosional surfaces. The lithofacies include packed foraminifer limestones (Pl. 1 - 2,4), and calcarenites in which sand-sized bioclasts are broken and entire larger foraminifera, coralline algae, bivalve and echinoderm fragments are present. Cm-sized fragments and entire sand dollars (Mellita sp.) occur in many beds. The nodularity is ascribed to intense burrowing and early lithification of the sediments. At Punta Nosara, along the south bank of the Nosara river mouth, we measured a roughly $200 \mathrm{~m}$ thick section in which 3 levels of bioclastic limestones are interstratified in the calcareous mudstones described above. The limestones represent the high energy facies where mud-sized particles are largerly washed out and probably deposited in a more distal facies. There is a clear increase in cross-stratification towards the top of each limestone interval and a general increase towards the top of the section.
Interpretation: Multidirectional high-angle trough cross-stratification is typical of a nearshore to offshore shallow, wave-dominated environment. Most of the carbonate was repeatedly reworked and displaced in submarine dunes. The only autochtonous fossils seem to be entire sand-dollars that must have lived as infauna in many beds.

\section{Volcanic mudstones and tempestites}

The bioclastic limestones are overlain through a sharp conformable contact by a section of tuffaceous light yellow to gray mudstones at least $100 \mathrm{~m}$ thick, alternating with distinct 5 to 50 $\mathrm{cm}$-thick volcaniclastic tempestites. The mudstones show few sedimentary structures, except for current lamination and some coarse-tail grading. The thin $(5-10 \mathrm{~cm}$ thick) tempestites show coarse tail grading, parallel and ripple lamination, and rest with a sharp, hummocky, erosive contact on the mudstones. Tempestite beds are distinctly 
more lithified and form sharp-edged reliefs on the marine platform. Thick tempestites are distinctly bimodal; a lower $10-20 \mathrm{~cm}$ thick dark green to black dense bed showing parallel and oblique lamination is mainly composed of altered basalt clasts and heavy minerals, especially hematite. The upper $20-40 \mathrm{~cm}$ thick layer is distinctly coarse-tail graded and ranges from coarse to fine sand size. It is composed mainly of light colored tuffaceous clasts, altered feldspars and some carbonates. It has a sharp flat contact with the lower dark bed. It shows parallel and scarce oblique lamination and grades upsection into the inter-tempestite mudstones.

Interpretation: While the light coloured yellowish and brownish mudstones and tempestites have clearly an intermediate to acidic, mature volcanic arc source, the black dense beds represent mainly heavy mineral lag deposits that are derived from the underlying basalts and intrusives of the Nicoya Complex. These rocks must have formed outcrops onshore and the erosional products were reworked and size selected in the shallow offshore area, to form lag deposits. These lags occur occasionally, but make less than $10 \%$ of the thickness of the section. Tempestites made of light coloured sandy, mostly tuffaceous material largerly dominate. Altered tuffs must also have contributed largerly to the clays and mud that constitute the offshore mudstones. Apart from poorly preserved planktonic foraminifera and some sponge spicules, no biodetritus has been found in this section. So far, the volcanic mustones and tempestites are undated, but if we consider the stratigraphic position above the Upper Oligocene, this sequence may reach into the lowest Miocene.

\section{Diversity of larger foraminifera at Punta Pela- das and Punta Nosara}

The bioclastic limestones of Punta Peladas and Punta Nosara have yielded rich assemblages of larger foraminifera that could be isolated and have been studied both in oriented, hand-ground sections, SEM for split material and polished rock thin sections for transmitted light and cathodoluminescence (CL) observation (BaumgartnerMora \& Baumgartner, 1994).
CL observation was essential for the taxonomic determination of the nepionic stage of miogypsinids, which are generally very recrystallized. CL observation revealed also a larger number of planktonic foraminifera associated with the shallow water material, confirming the open marine environment indicated by the sedimentology of the carbonates at Punta Peladas. Planktonic foraminifera are under study in thin sections.

The association of larger foraminifera at Punta Peladas ( $9^{\circ} 56^{\prime}$ 57” N, 85 40'40.60” W) are: Amphistegina sp., Heterostegina antillea Cushman (Pl. $1-7,8)$, Heterostegina israelksyi Gravell and Hanna, Miogypsina tani Drooger (Fig4a, Pl.1 - 5, 6; Pl.2 - 1, 2, 5, 6), Miogypsina gunteri Cole (Fig. 4b; Pl. 2 - 3, 4), Miogypsina cf. (Miolepidocyclina) panamensis (Cushman), Miogypsina sp., Lepidocyclina (Nephrolepidina) vaughani Cushman (Pl. 1 - 4, 9), Lepidocyclina yurnagurensis Cushman (Pl. 1 - 4), Lepidocyclina undosa Cushman. New species of Miogypsina are currently under study. We note that the genus Miogypsinoides, known since the Middle Oligocene, is very rare in the studied assemblages.

\section{Systematic notes on Miogypsina from Nosara}

Nuttal (1933) described two Oligocene species of Miogypsina from the Tampico embayment of Mexico. Miogypsina mexicana Nuttal, from Llower Oligocene and Miogypsina complanata Schlumberger, from middle Oligocene, were placed in the genus Miogypsinoides Yabe \& Hanzawa 1928 by several authors based on morphological features. The species Miogypsinoides complanatus should not be found in strata younger than Late Oligocene (Adams, 1983; Drooger, 1963). Miogypsinoides complanatus is rare in the samples from Nosara. It is, however, well present in bioclastic limestone blocks of Cañablancal river, north of Jacó (Herradura block, Pacific coast, Costa Rica).

The systematics of Miogypsina used here, requires some explanation. Cole $(1964,1967)$ considered only the species which differ in the number of principal auxiliary chambers as valid in America. Based on this concept, he recognized 
only two species: Miogypsina panamensis, with one principal auxiliary chamber and Miogypsina antillea, with two principal auxiliary chambers. As a consequence, Cole (1964) considered M. gunteri and M. tani as synonymous of M. panamensis, for which he proposed a range restricted to the Oligocene. This concept is not followed in this work because we can clearly identify the morphological characters of the two species M. gunteri and M.tani.

Two principal types of Miogypsina are identified in the samples of Nosara (Pl. 2). Both have an apical position of the periembryonic coil (Fig. 4). The first type, identified as Miogypsina tani, has the nucleoconch ( $\mathrm{P}=$ protoconch, $\mathrm{D}=$ deuteroconch) in contact with the margin of the test (Fig. 4a Pl.2 - 1, 2, 5, 6). It has a uniserial nepionic arrangement, but sometimes a biserial arrangement is suspected. The second type, identified as Miogypsina gunteri, has the nucleoconch separated from the margin of the test by the operculinoid chambers of the single spiral coil (Fig. 4b, Pl. 2-3,4). These two species form part of the group Miogypsina basraensis- M. tani of Drogger (1952)

Species of this group can be distinguished on the basis of the number of spiral chambers in the first whorl, including the principal auxiliary chamber (X-value of Drooger, 1952). In our material from Nosara, the X-value of Miogypsina tani (Fig 4a) ranges form 6 to 9 and that of Miogypsina gunteri (Fig. 4b) from 9 to 12.5 .

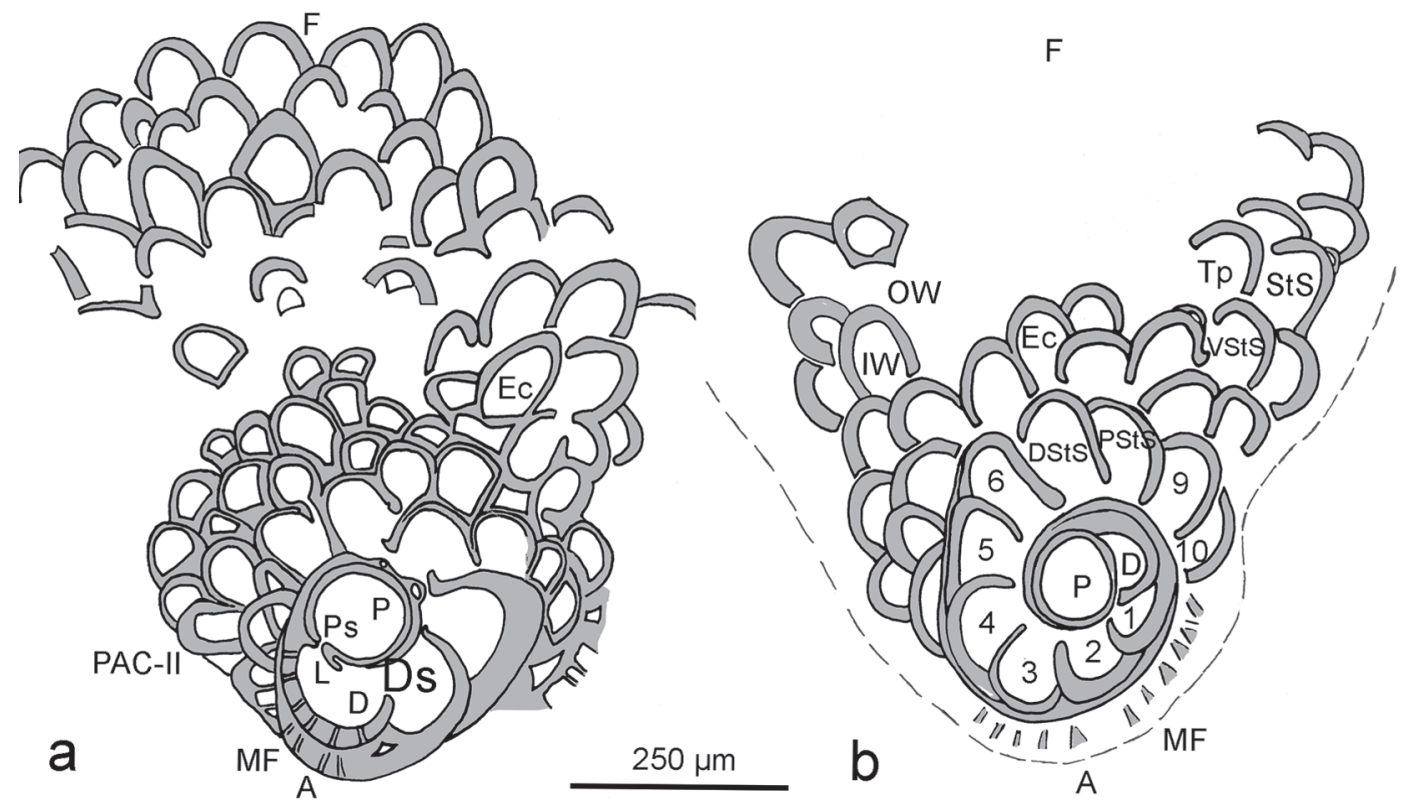

Fig. 4: Schematic drawings of the aequatorial sections of Miogypsina sp. The nomenclature of the morphological features shown follow the terminology of de Bock (1976).

a. Miogypsina tani Drooger illustrated by cathodoluminescence on Pl. 1- Fig. 5. The embryonic apparatus composed of protoconch (P) and deuteroconch (D) is situated at the periphery of the test, the deuteroconch is directly in contact with the marginal fringe (MF) in the apex (A) of the test. The specimen is cut through the protoconchal stolon (Ps). The lip (L) near the Ps is observed. Cement between the wall of the deuteroconch and the wall of the protoconch put in evidence the funnel-shaped of the deuteroconchal stolon (Ds). This specimen has one principal auxiliary chamber and one smaller second principal auxiliary chamber (pac-II) on the side of the Ps. In the spiral wall (inside the MF), many small openings with a clear cement are interpreted as pores. Many equatorial chambers (Ec) are visible. Sample CM 1121.37, Punta Peladas.

b. Miogypsina gunteri Drooger showing ten spiral chambers $(\mathrm{X}=10)$ and a coarse marginal fringe (MF). Sample CM 1121.36, Punta Peladas. 


\section{WINDWARD, CARRIACOU (LESSER ANTILLES): SEDIMENTOLOGY AND LARGER FORAMINIFERA}

\section{Location, lithology and sedimentology}

The outcrops around Windward (Fig. 3), originally described by Robinson \& Jung (1972) as "Windward Limestones abd Tuffs" were included with the Belvedere Formation, described overall by Speed et al. (1993) as well bedded interstratified pelagic marls and volcanogenic turbidites with occasional conglomeratic beds. These authors noted that larger foraminifera occur sporadically as minor constituents of pebbly sandstones throughout the formation.

The coastal outcrops sampled for this study are located along low bluffs on the south side of the little bay north of Windward Village (12 $30^{\circ}$ 54.29 ” N, $61^{\circ} 25$ ' 49.25" W). They expose a 10$15 \mathrm{~m}$ section of interbedded light yellow tuffaceous hemipelagic marls and distinctly laminated limestones that are cemented foraminifer conglomerates. The limestones occur in 20 to $60 \mathrm{~cm}$ thick beds in which coastal weathering has carved out the more marly laminae, leaving in relief $\mathrm{cm}-$ to $\mathrm{dm}$-thick layers of foraminifer conglomerates. The mostly entire larger foraminifera are well oriented parallel to bedding and may be extracted in some places from the marly matrix. The lamination/bedding is mostly parallel, but some low angle unconformities occur between bundles of laminae within limestone beds. The hemipelagic marls form 10 to $80 \mathrm{~cm}$-thick more or less lithified chalky intervals that are mostly massive, with irregular layers of nodules, probably due to differential lithification of burrows. Limestone beds seem to be concentrated in levels between the houses of Windward village scattered thick beds of foraminifer limestones stick out of the ground and mark another level.

The limestone certainly represent turbidites of shallow water origin emplaced into a pelagic, deep water paleoenvironment. However, size grading is not evident and often irregular within one bed. Besides, parallel and rare oblique lamination suggesting $\mathrm{Tb}$ and $\mathrm{Tc}$ Bouma sequences, are not visible. Either the beds represent multiple amalgamated turbidites, or original turbidites were reworked and winnowed by bottom currents. Taking into account the low density of larger foraminifer tests, even $\mathrm{cm}$-sized specimens are easily transported either in turbidity currents or winnowed by bottom currents. However, size grading may also be inconspicuous due to the small size/density range of larger foraminifera.

\section{Biostratigraphy}

At our Windward locality, the calciturbidites rich in larger foraminifera are interbedded with hemipelagic marls from which Westercamp et al. (1985) extracted an early Late Oligocene planktonic foraminifer assemblage (Cari 15: NP24). Blow (in Robinson \& Jung, 1972) reported definite N2zone planktonic faunas associated with Miogypsina septentrionalis and Miogypsina gunteri in Lehner's collection from the same locality. These findings indicate a Late Oligocene minimum age for the displaced larger foraminifera in the limestones.

Robinson \& Jung (1972) reported from outcrops 10761 and 10762, about $500 \mathrm{~m}$ north of our site, the presence of Heterostegina antillea, Miogypsina panamensiss (of Cole 1958), Lepidocyclina canellei and Nephrolepidina vaughani (of Cole 1958). Planktonic foraminifera recovered further south between Windward and Dover in rocks slightly downsection by Robinson \& Jung (1972), indicate a late Middle Oligocene age by the presence of Globorotalia opima opima. These authors cite here the same content in larger foraminifera as in sample 10762 cited above, with the addition of Eulepidina undosa, Operculinoides dias and Miogypsinoides sp. Nannofossils determined by (Speed et al. 1993) indicate N23-24 and N24-25 (late Early to Late Oligocene) ages for the same area.

From our site, we collected in addition to the species mentioned above, Lepidocyclina undosa Cushman and Miogypsina gunteri Cole. In summary, we can state that the occurrences of Miogypsina sp. in the outcrops around Winward are associated with planktonic assemblages not younger than Late Oligocene. 


\section{AGE CALIBRATION BY MEANS OF STRONTIUM ISOTOPE STRATIGRAPHY}

\section{Theory and age calibration methods}

Strontium has four stable isotopes $\left({ }^{84} \mathrm{Sr},{ }^{86} \mathrm{Sr}\right.$, ${ }^{87} \mathrm{Sr}$, and ${ }^{88} \mathrm{Sr}$ ). Of these four, ${ }^{87} \mathrm{Sr}$ is the radiogenic product of decaying ${ }^{87} \mathrm{Rb}$ and reflects therefore the changing balance between relatively radiogenic strontium from weathering of old continental crust (e.g. Edmond, 1992; Galy et al., 1999) and relatively non-radiogenic strontium supplied to the oceans by mid-oceanic ridge hydrothermal fluids, but uncertainties on the contribution of hydrothermal strontium fluxes exist (e.g. Davis et al., 2003; Jones \& Jenkyns, 2001). By incorporation of $\mathrm{Sr}$ in mainly biogenic carbonates -particularly skeletal aragonite-, $\mathrm{Sr}$ is removed from the oceans. Hence, $\mathrm{Sr}$ captured in the $\mathrm{CaCO}_{3}$ structure of calcareous marine fossils should reflect seawater strontium isotope ratios of the time of biomineralization and/ or early diagenesis of the carbonate shells. Sr can be chemically extracted and analysed, allowing the reconstruction of a seawater strontium isotope curve over Earth's history. Considering the long residence time of dissolved $\mathrm{Sr}$ in the oceans in the size of 2 million years compared to the estimated ocean mixing time of less than 2000 years (Vonhof, 1998), Sr is isotopically homogeneous in seawater at any given time, offering good perspectives on global correlation of marine sedimentary rocks. Vital effects are not known at present analytical precision (Reinhardt et al., 1999).

The record of marine ${ }^{87} \mathrm{Sr} /{ }^{86} \mathrm{Sr}$ for the Phanerozoic has been analyzed in numerous studies (e.g. Burke et al., 1982; Veizer et al., 1999). McArthur et al. (2001) presented a best-fit curve calculated by nonparametric LOWESS (Locally Weighted Scatter Plot Smoother) statistical regression function, mainly based on critically revised ${ }^{87} \mathrm{Sr} /{ }^{86} \mathrm{Sr}$ isotopic data from literature. Assignments of numerical ages to ${ }^{87} \mathrm{Sr} /{ }^{86} \mathrm{Sr}$ isotopic data from literature were converted for calibration using the formula of Wei (1994) and the stage boundaries of Gradstein et al. (1995) as temporally nearest pair of numerically dated stratigraphic tie-points. The resulting best-fit curve with its $95 \%$ confidence intervals have been converted into a table giving numerical ages and their $95 \%$ confidence limits for any given ${ }^{87} \mathrm{Sr} /{ }^{86} \mathrm{Sr}$ value, by interpolation in steps of 0.000001 . A table converting numerical ages to interpolated values of marine ${ }^{87} \mathrm{Sr} /{ }^{86} \mathrm{Sr}$, provided by McArthur et al. (2001), allows a simple assignment of numerical ages to measured ${ }^{87} \mathrm{Sr} /{ }^{86} \mathrm{Sr}$ values.

\section{Sample selection and laboratory procedures}

To select samples for Sr-isotope measurements, polished thin sections were examined under cathodoluminescence (CL). This allows detecting reworked material recognisable by its different (in general more luminescent) CL. We selected samples with homogeneous CL and low detritical content. The billet corresponding to the thin section was first rinsed with $\mathrm{HCl} 1 \%$ and washed with distilled water in an ultrasonic bath. The wall of larger benthic foraminifera was drilled using a dentist's drill under the binocular lens to obtain the powder for the measurements.

14.4 M, $3 \mathrm{M}$ and $0.01 \mathrm{M} \mathrm{HNO}_{3}$ were used for $\mathrm{Sr}$ separation with $\mathrm{Sr}$-resin (Eichrom Inc., Darien, US) and were prepared in laboratory from distilled $65 \%$ concentrated $\mathrm{HNO}_{3}$ ('pro analysis', Merck, Darmstadt, Germany, Sr content $<1 \mathrm{ppm}$ ). $2.2 \mathrm{M} \mathrm{CH}_{3} \mathrm{COOH}$ was prepared in the laboratory from distilled $100 \%$ concentrated $\mathrm{CH}_{3} \mathrm{COOH}$ ('pro analysis', Merck, Sr content $<0.005 \mathrm{ppm}$ ). Millipore water was used for the preparation of all solutions and dilutions. Only acid-cleaned FEP Teflon beakers (cleaned in $5 \mathrm{M} \mathrm{HNO}_{3}$ followed by $6 \mathrm{~N} \mathrm{HCl}$ for $12 \mathrm{~h}$ each) were used.

The columns used for $\mathrm{Sr}$ separation were prepared in the laboratory using $1000 \mu \mathrm{l}$ pipette tips and a lower frit of PE-fine sheet (Porex Technologies Inc., Singwitz, Germany). Prepared pipette tips were stored in $0.01 \mathrm{M} \mathrm{HNO}_{3}$. About $0.25 \mathrm{~g}$ of $\mathrm{Sr}$ resin was introduced as a suspension in $3 \mathrm{M} \mathrm{HNO}_{3}$ into the prepared pipette tips and the columns conditioned by rinsing with $2 \mathrm{~mL} 3$ $\mathrm{M} \mathrm{HNO}_{3}$. Sample powder was dissolved in 2.2 $\mathrm{M}$ acetic acid, to avoid leaching of $\mathrm{Sr}$ from detrital minerals in the limestone. Insoluble residues were separated by centrifugation and the acetic acid was evaporated. $0.2 \mathrm{~mL}$ of $14.4 \mathrm{M}$ nitric acid was added to the sample and was then evaporated to dryness in order to oxidise organic matter 
(McArthur et al., 2001). The sample was loaded with $0.5 \mathrm{~mL} 3 \mathrm{M} \mathrm{HNO}_{3}$ and rinsed with about 1.5 $\mathrm{mL} 3 \mathrm{M} \mathrm{HNO}_{3}$ to wash out the non-retained elements. Sr was eluted with about $1.5 \mathrm{~mL} 0.01 \mathrm{M}$ $\mathrm{HNO}_{3}$. Total laboratory blanks for $\mathrm{Sr}$ (including chemicals, column and loading blank) did not exceed $0.25 \mathrm{ng}$.

Samples were analyzed at the Geological Institute of the University of Berne. The isotopic composition of the $\mathrm{Sr}$ was determined with a $\mathrm{Nu}$ Instruments ${ }^{\circledR}$ multicollector ICP mass spectrometer operated in static mode. The measured ${ }^{87} \mathrm{Sr} /$ ${ }^{86} \mathrm{Sr}$ ratio was normalized to the natural ${ }^{88} \mathrm{Sr} /{ }^{86} \mathrm{Sr}$ of 8.375209 for the ratio. The number of collected ratios per measurement was $n=120$. After measurement of each third sample, the NBS987 standard was measured and sample measurements were adjusted to the certified value for the NBS987 of 0.710248. A total of 8 standards (NBS987) were measured with an average ${ }^{87} \mathrm{Sr} /{ }^{86} \mathrm{Sr}$ of $0.710240(2$ s.d. $=0.00004)$.

\section{Results}

The ${ }^{87} \mathrm{Sr} /{ }^{86} \mathrm{Sr}$ ratio was measured in 11 specimens of megalosphaeric Lepidocyclina sp. mechanically extracted from several rock samples collected at Punta Peladas ( $9^{\circ} 56^{\prime} 57^{\prime}$ N, $85^{\circ}$ 40' 40.60" W, Costa Rica) a few $m$ above the angular unconformity with the underlying deep water series. ${ }^{87} \mathrm{Sr} /{ }^{86} \mathrm{Sr}$ ratios range from 0.70809 to 0.70820 , which corresponds to model ages between 27.3 and 24.9 Ma (Fig. 5) according to McArthur et al. (2001). This age range does not represent the duration of sedimentation, since the samples were taken in a stratigraphic interval of a few $\mathrm{m}$ only. It could represent isotopic variations during early diagenesis that variably affected different samples and different specimens in each sample.

Very similar ${ }^{87} \mathrm{Sr} /{ }^{86} \mathrm{Sr}$ ratios, ranging from 0.70815 to 0.70817 (Fig. 5) were obtained from two specimens extracted from a sample collected in a coastal outcrop $\mathrm{N}$ of Windward Village $\left(12^{\circ}\right.$ 30' 54.29” N, 61 ${ }^{\circ} 25$ ' 49.25 W, Carriacou, Lesser Antilles). All measured ${ }^{87} \mathrm{Sr} /{ }^{86} \mathrm{Sr}$ ratios fall within a Chattian (Late Oligocene) age according to the Berggren et al. (1995) time scale.

\section{DISCUSSION}

The biochronologic range of M. tani and M. gunteri is currently controversial, and has to be considered as poorly known. At present, there are two concepts of the first appearance of these species, discussed below.

\section{Oligocene first occurrence}

In America, Miogypsina gunteri was originally described by Cole (1938) in the Suwannee limestone of Florida of the Upper Oligocene, this age was contested by Drooger (1952), which suggested a Middle Oligocene for Cole's sample.

In Trinidad, Miogypsina gunteri was found in Oligocene sediments (Vaughan \& Cole, 1941; Caudri, 1996). Cole (1964) considered M. gunte$r i$ and M.tani as synonymous of M. panamensis, for which he proposed a range restricted to the Oligocene. As discussed above under "Systematic notes on Miogypsina", this concept was not followed in this work because we can clearly identify the morphological characters of the two species M.gunteri and M.tani.

M. tani was originally described by Drooger (1952) from a sample collected from "Oligocene" outcrops of fossiliferous conglomerate along the Reventazón river (Costa Rica). He assigned a Middle Oligocene age to this form. Later, Cole (1961) examined a sample sent by E. Malavassi V. from the same locality and found Lepidocyclina undosa associated with Miogypsina tani. Malavassi (1961) correlated the outcrops of Punta Peladas discussed here with the Upper Oligocene portion of the Caimito and Bohio formations of Panama (Cole, 1952).

\section{Miocene first occurrence}

In Europe, according to Drooger (1955, 1956a), the range of M. gunteri begins in the oldest Aquitanian (Lower Miocene) in the Aquitanian Basin of France. DeBock (1976) found M. gunteri in several localities of the Aquitanian basin that he assigned to an early to late Aquitanian age. In the European realm, M.tani is known from the 


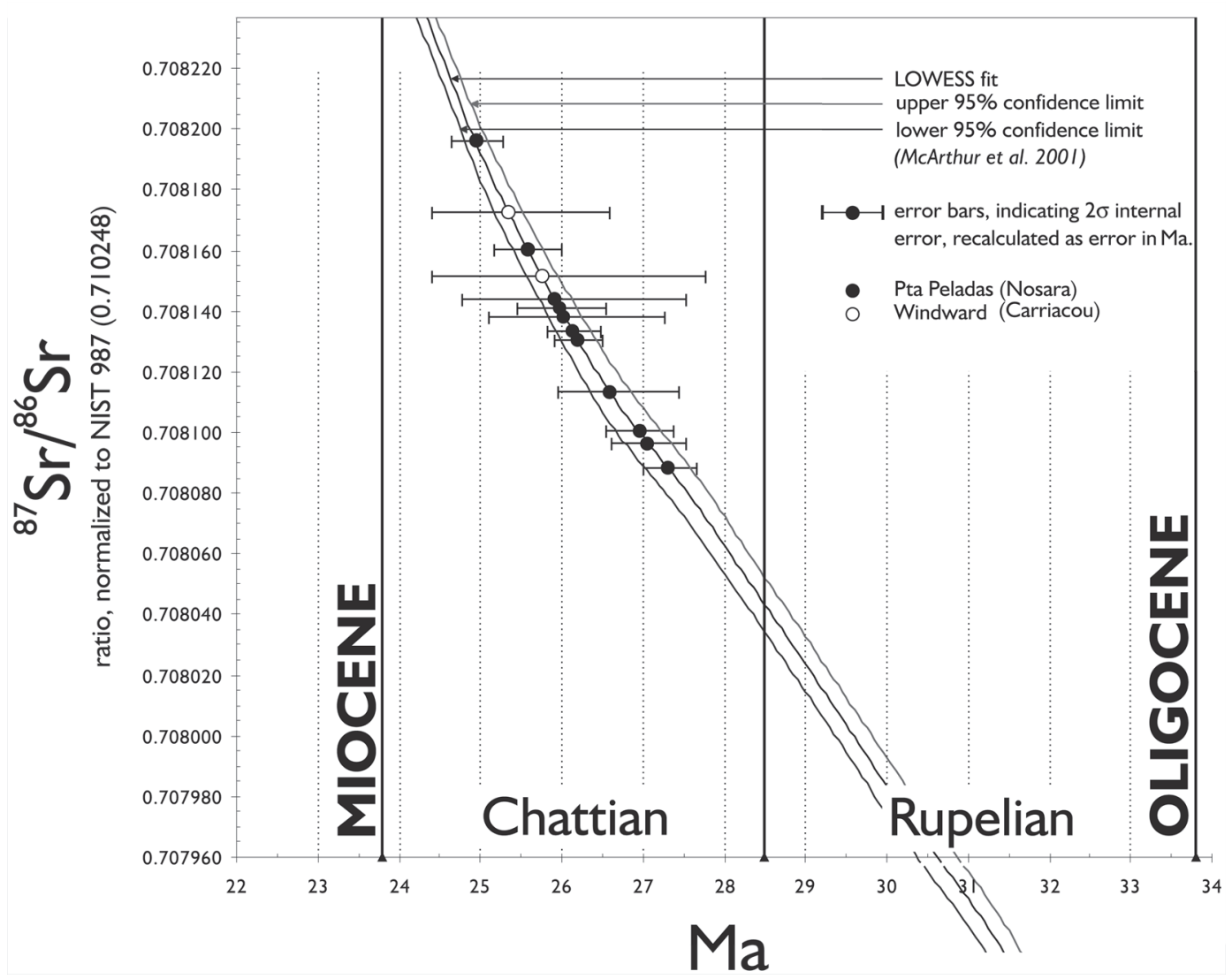

Fig. 5: $87 \mathrm{Sr} / 86 \mathrm{Sr}$ strontium isotope ratios measured in samples from Punta Peladas (full circles) and Windward (empty circles), plotted against age (Ma) according to McArthur et al. (2001). All values, including 2 sigma analytical errors, are recalculated as errors in Ma fall within the Chattian (Late Oligocene) stage.

stratotype of the Aquitanian stage and has a wide geographical distribution (Raju, 1974; Adams, 1983). M. gunteri and M. tani are considered by Cahuzac \& Poignant (1997) as successive markers for their Aquitanian biozone SB 24 (shallow benthic foraminiferal biozone). However, already Drooger $(1954,1956 b)$ clearly stated that the latest Oligocene strata below the type Aquitanian do not contain larger foraminifera because of a probable freshwater influence. To us, it seems clear that the first occurrence of Miogypsina in the type Aquitanian of the Aquitanian Basin is facies-controlled.

Butterlin (1981), in his work on the Caribbean and Mexico followed the European school and restricted the range of Miogypsina gunteri to the early Aquitanian (Early Miocene) and that of M. tani to the late Aquitanian, despite of contradicting evidence in
America. Also Askers \& Drooger (1957), described M. gunteri and M.tani in sediments of the Gulf Coast and argued in favour of an Aquitanian age, an assumption that was put in doubt by Malavassi (1961).

The association of larger foraminifera of Nosara and Windward can clearly be compared with late Oligocene assemblages described by Caudri (1996) from Trinidad. M. gunteri is cited by this author from Kapur Quarry in the Cipero Formation in SE Trinidad, which was dated by the Globigerina ciperoensis ciperoensis and Globorotalia kugleri zones of Late Oligocene age according to Bolli \& Saunders (1985). Later, Berggren et al. (1995) placed the G. kugleri zone in the earliest Miocene. However, it should be noted that the Cipero Formation is a muddy deep water formation in which the shallow water material of 
the Kapur Quarry may be reworked from considerably older formations (Eames et al., 1960, 1962; Caudri 1996).

Díaz de Gamero (1977) found Lepidocyclina undosa, Heterostgina antillea and M. gunteri below the first appearance datum of Globigerinoides primordius (latest Oligocene/ earliest Miocene according to Berggren et al., 1995) in the Pecaya and Pedregoso formations of Venezuela.

The species commonly associated with $\mathrm{M}$. gunteri and M. tani in the Caribbean region are Heterostegina antillea Cushman, Lepidocyclina (Nephrolepidina) vaughani Cushman and Lepidocyclina undosa. They seem to have a range from the Middle Oligocene Globorotalia opima zone to the Early Miocene Catapsydrax dissimilis zone (Andreieff et all., 1987; Caudri 1996). According to Berggren et al. (1995), the Catapsydrax dissimilis zone is of Middle Miocene age.

In summary, there are clear evidences of an at least Late Oligocene (Chattian) first occurrence of M. tani and M. gunteri in America. Such an age is in accordance with nannofossil and planktonic foraminifer data form Carriacou. Identical Sr-ratios from Nosara and Windward confirm a Chattian age for these assemblages and contradict a restriction of M. gunteri and M. tani to the early Miocene as proposed by some European workers. The apparent later first occurrence of these species in Europe may be facies-controlled at the type locality of the Aquitanian, which may have induced errors of correlation throughout Europe. An additional problem of correlation arises from repeated revisions of the zonal schemes for planktonic foraminifera around the Oligocene/Miocene boundary.

\section{CONCLUSIONS}

Nannofossils and planktonic foraminifera from Windward (Carriacou), and identical ${ }^{87} \mathrm{Sr} /$ ${ }^{86} \mathrm{Sr}$ ratios from both Punta Peladas and Windward clearly indicate a Chattian (Late Oligocene) occurrence of Miogypsina gunteri and Miogypsina tani and confirm this age range for the associated larger foraminifera cited above.

The ${ }^{87} \mathrm{Sr} /{ }^{86} \mathrm{Sr}$ ratio measured in the calcite of larger foraminifera provides consistent values reflecting the strontium isotopic composition of seawater at the time of biomineralization and/or early diagenesis of the foraminifer tests. These values can be interpreted in terms of absolute ages by using calibration curves such as the one proposed by McArthur et al. (2001). The middlelate Tertiary interval is ideal for such an approach since the ${ }^{87} \mathrm{Sr} /{ }^{86} \mathrm{Sr}$ ratio increased at a high rate of $2.6 \times 10^{-4} \mathrm{Ma}^{-1}$. At such a rate, the majority of our measurements allow an absolute age call with an error of $< \pm 1$ Ma.

The co-occurrence of the two species in the Late Oligocene does, at least for Central America, makes infirm their successive first occurrence in the Early Miocene and their use as marker species for an Aquitanian biozone.

\section{ACKNOWLEDGEMENTS}

We owe much of the advancement of this work to the critical view of Prof. Lukas Hottinger (University of Basel) who always had time and patience for teaching and discussion. We are thankful to Prof. Jan Kramers (University of Berne) for his dedication to our measurements on his multicollector ICPMS. Thanks to the hospitality of Dario Sandrini and Maria Fastigi (KIDO Project, Carriacou), our field work in Carriacou was greatly facilitated. Field and laboratory work was carried out in the frame of projects granted by the Swiss National Science Foundation ( $\mathrm{N}^{\circ} 2000-063762$ and $\mathrm{N}^{\circ}$ 200021-105845). Additional support for field work was provided by the Foundation Herbette granted to Natural Sciences at the University of Lausanne. The authors are thankful to Prof. Percy Denyer and Prof. Teresita Aguilar (both at University of Costa Rica) for stimulating discussions and final revision of the manuscript.

\section{REFERENCES}

ADAMS, C.G., 1983: Speciation, phylogenesis, tectonism, climate and eustasy: Factors in the evolution of Cenozoic larger foraminiferal bioprovinces. - In: SIMS, R.W., PRICE, J.H. \& WHALLEY,(eds): Evolution, Time and Space. - Systematics Assoc. Spec. Vol. 23: 255-289. 
AGUILAR, T., 1999: Organismos de un arrecife fósil (Oligoceno Superior-Mioceno Inferior) del Caribe de Costa Rica. - Rev. Biol. Trop. 47 (3): 453-474.

ASKERS, W.H., \& DROOGER, C.W., 1957: Miogypsinids, planktonic foraminifera, and Gulf Coast Oligocene-Miocene correlations. - Bull. Am. Assoc. Petrol. Geol. 41: 656-678.

\section{ANDREIEFF,P.,BOUYSSE,P.\&WESTERCAMP,} D., 1987: Géologie de L'Arc insulaire de Petites Antilles, et evolution géodynamique de l'Est-Caraïbe. -356 p. Université de Bordeaux [Doctorate Thesis].

BAUMGARTNER, P.O., MORA, C.R., BUTTERLIN, J., SIGAL, J., GLACON, G., AZEMA, J., \& BOURGOIS, J., 1984: Sedimentación y paleogeografía del Cretácico y Cenozoico del litoral pacífico de Costa Rica. - Rev. Geol. Amér. Central, 1: 57-136.

BAUMGARTNER-MORA, C., TSCHUDIN, P. \& BAUMGARTNER, P.O., 2005: Late Oligocene Caribbean assemblages of Larger Foraminifera calibrated by $87 \mathrm{Sr} /$ 86Sr (Nicoya Costa Rica and Carriacou, Lesser Antilles). - [Abstract] 17th Caribbean Geological Conference, San Juan, Puerto Rico, p. 4.

BERGGREN, W.A., HOLDEN, F.J., LANGERIES, C.G., KENT, D.V., OBRADOVITCH, J.D., RAFFI, I., RAYMO, M.\& SACKLETON, N.J., 1995: Late Neogene (Pliocene-Pleistocene) chronology: New perspectives in high-resolution stratigraphy. - Geol. Soc. Am. Bull. 107: 1272-1287.
BOLLI,H.M.\& SAUNDERS, J.B., 1985: Oligocene to Holocene low latitude planktic foraminifera. - In: Bolli, H.M., Saunders, J.B. \& PerchNielsen, K. (eds): Plankton Stratigraphy. Cambridge Earth Science Series. Cambridge University Press, 155-262.

BURKE, W.H., DENISON, R.E., HETHERINGTON, E.A., KOEPNICK, R.B., NELSON, H.F. \& OTTO, J.B., 1982: Variations of seawater $87 \mathrm{Sr} / 86 \mathrm{Sr}$ throughout Phanerozoic time. - Geology, 10: 516-519.

BUTTERLIN, J., 1981: Claves para la determinación de macroforaminíferos de México y del Caribe, del Cretácico Superior al Mioceno Medio. - 219 p. Instituto Mexicano del Petróleo, México.

CAHUZAC, B. \& POIGNANT, A., 1997: Essai de biozonation de l'Oligo-Miocène dans les basins Européens à l'aide des grands foraminifers néritiques. - Bull. Soc. Géol. France, 168: 155-169.

CAUDRI, B., 1996: The Larger Foraminifera of Trinidad (West Indies). - Eclogae Geol. Helv. 89: 1137-1309.

COLE, W.S., 1938: Stratigraphy and micropaleontology of two deep wells in Florida.- U.S. Geol. Surv. Bull., 16:1-73 + 12 plates.

COLE, W.S., 1952: Eocene and Oligocene Larger Foraminifera from Panama Canal Zone and Vicinity. - U.S. Geol. Surv. Prof. Paper, 244: $1-41+28$ plates.

COLE, W.S., 1958: Larger foraminifera from Carriacou (B.W.I.). - Bull. Amer. Paleontol. 38 (171): 219-233. 
COLE, W.S., 1961: Some nomenclatural and stratigraphic problems involving Larger Foraminifera. - Contrib. Cushman Found. Foram. Res. 12 (4): 136-147 + 17 plates.

COLE, W.S., 1964: American Mid-Tertiary miogysinid Foraminifera: classification and zonation. - Contrib. Cushman Found. Foramin. Res., 15(4): 138-150, Ithaca, New York.

COLE, W.S., 1967: A revue of American Species of Miogypsinids (Larger Foraminifera).Contrib. Cushman Found. Foram. Res. 18 (3): 99-117.

DAVIS, A.C., BICKLE M.J. \& TEAGLE D.A.H., 2003: Imbalance in the oceanic strontium budget. - Earth Plan. Sc. Let. 211: 173-187.

DENGO, G., 1962: Estudio geológico de la región de Guanacaste, Costa Rica. - 112 p. IGN, San José.

DE BOCK, J.F., 1976: Studies on some Miogypsinoides-Miogypsina s.s. associations with special reference to morphological features. - Scripta Geol. 36: 1-136.

DÍAZ DE GAMERO, M.L., 1977: Estratigrafia y micropaleontologia del Oligoceno y Mioceno inferior del centro de la Cuenca de Falcón, Venezuela.- Geos., Univ. Central Venezuela, 22:2-50.

DROOGER, C.W., 1952: Study of American Miogypsinidae.- 80 p. Univ. Utrecht., Netherlands [Doctor's thesis].

DROOGER,C.W., 1954: The Oligocene-Miocene boundary on both sides of the Atlantic. Geol. Magazin, 91(6): 514-518.
DROOGER, C.W., 1955: Remarks on Cycloclypeus, I and II. - Proc. Koninkl. Nerderl. Akademie van Wetenschappen, 58 (5): 415-433, Amsterdam.

DROOGER, C.W., 1956a: Parallel Evolutionary trends in Larger Foraminifera. - Koninkl. Nederl. Akademie van Wetenschappen. Series B, 5: 458-469, Amsterdam.

DROOGER, C.W., 1956b: Transatlantic correlation of the Oligo-Miocene by means of Foraminifera. - Micropaleontology, 2 (2): 183-192.

DROOGER, C.W., 1963: Evolutionary trends in the Miogypsinidae.-In:vonKoenigswal, G.H.R., Emeis, J.D., Buning, W.L. \& Wagner, C.W. (ed.): Evolutionary Trends in Foraminifera. - Elsevier, Amsterdam, 314-349.

EAMES, F.B., BANNER, F.T., BLOW, W.H. \& CLARKE, W.J., 1960: Mid-Tertiary stratigraphical palaeontology. - Nature, 185 (4711): 447-448.

EAMES, F.B., BANNER, F.T., BLOW, W.H. \& CLARKE, W.J., 1962: Fundamentals of Mid-Tertiary Stratigraphical Correlation. - 163. Cambridge University Press.

EDMOND, J.M., 1992: Himalayan tectonics, weathering processes and the strontium isotope record in marine limestone. - Science, 258: 1594-1597.

GALY, A., FRANCE-LANORD, C. \& DERRY, L.A., 1999: The strontium isotopic budget of Himalayan rivers in Nepal and Bangladesh. - Geochim. Cosmochim. Acta, 13/14: 1905-1925. 
GRADSTEIN, F.M., AGTERBERG, F.P., OGG, J.G, HARDENBOL, J., VEEN, P. VAN \& HUANG, Z., 1995: A Mesozoic time scale. - J. Geophys. Res. 99(B12): 24051-24074.

JONES, C.E. \& JENKYNS, H.C., 2001: Seawater Strontium Isotopes, oceanic anoxic events and seafloor hydrothermal activity in the Jurassic and Cretaceous.- Amer. J. Sci., 301: 112-149.

LEHNER, E., 1935: Report on the possibilities of establishing an artesian water supply for the island of Carriacou, with appended notes on the general geology of Carriacou. 16 p. Govern. Printing Office, St. George, Grenade [Int. report].

MALAVASSI,E., 1961: Some Costa Rican Larger Foraminifera localities. - J. Paleontol., 35: 498-501.

MARTIN-KAYE, P.H.A., 1958: The geology of Carriacou. - Bull. Amer. Paleontol., 38: 311-324.

MCARTHUR, J.M., HOWRATH, R.J. \& BAILLEY, T.R., 2001: Strontium Isotope Stratigraphy: LOWESS version 3: Best fit to the marine Sr-Isotope curve for 0-509 Ma and accompanying look-up table for deriving numerical age. - J. Geol., 109: $155-170$

NUTTAL, W.F.L., 1933: Two species of Miogypsina from the Oligocene of Mexico. - J. Paleontol., 7: 175-177.

RAJU,D.S.N.,1974: Study of Indian Miogypsinidae. - Utrech Micropal. Bull. 9: 1-148.

ROBINSON,E.A.\&JUNG,P.,1972: Stratigraphy and age of marine rocks, Carriacou, West Indies. Am. Assoc. Petrol. Geol. Bull. 56: 114-217.
REINHARDT, E.G., BLENKINSOP, J. \& PATTERSON R.T., 1999: Assessment of a $\mathrm{Sr}$ isotope vital effect $(87 \mathrm{Sr} / 86 \mathrm{Sr})$ in marine taxa from Lee Stocking Island, Bahamas. - Geo-Marine Let. 18: 241-246.

SPEED, R.C., SMITH-HOROWITZ, P.L. PERCH-NIELSEN, K.V.S., SAUNDERS, J.B. \& SANFILIPPO, A.B., 1993: Southern Lesser Antilles Arc Platform: Pre-Late Miocene Stratigraphy, Structure and Tectonic Evolution. - Geol. Soc. Am. Spec. Paper, 277: 1-98.

SPRECHMANN,P.(ed.), 1984: Manual de Geología de Costa Rica. - 320 p. Ed. UCR, San José.

VAUGHAN,T.W.\& COLE,W.S., 1941:Preliminary report on the Cretaceous and Tertiary larger foraminifera of Trinidad, British West Indies. - U.S. Geol. Surv. Spec. Paper, 30: 1-137.

VEIZER, J.D., AZMY ALA, K., BUCKSCHEN, P., BUHL, D., BRUHN, F., CARDEN, G.A., DIENER, A., EBNETH, A.S., GODDERIS, Y., JASPER, T., KORTE, C., PAWELLEK, F., PODHALA, O.G. \& STRAUSS, H., 1999: ${ }^{87} \mathrm{Sr} /{ }^{86} \mathrm{Sr}, \delta^{13} \mathrm{C}$ and $\delta^{18} \mathrm{O}$ evolution of Phanerozoic seawater. - Chem. Geol. 161 (1-3): 59-88.

VONHOF, H.B., 1998: The strontium isotope record of selected geologic events. $-178 \mathrm{p}$. Univ. of Amsterdam. [Ph.D. thesis].

WEI, W., 1994: Age conversion table for different time scales. - J. Nannoplankton Res. 16, (2): 71-73.

WESTERCAMP, D., ANDREIEFF, P., BOUYSSE, P., MASCLE, A., \& BAUBRON, J.-C., 1985: Géologie de l'Archipel des Grenadines (Petites Antilles méridionales) : étude monographique. - Documents du BRGM, 92:1-198, France. 

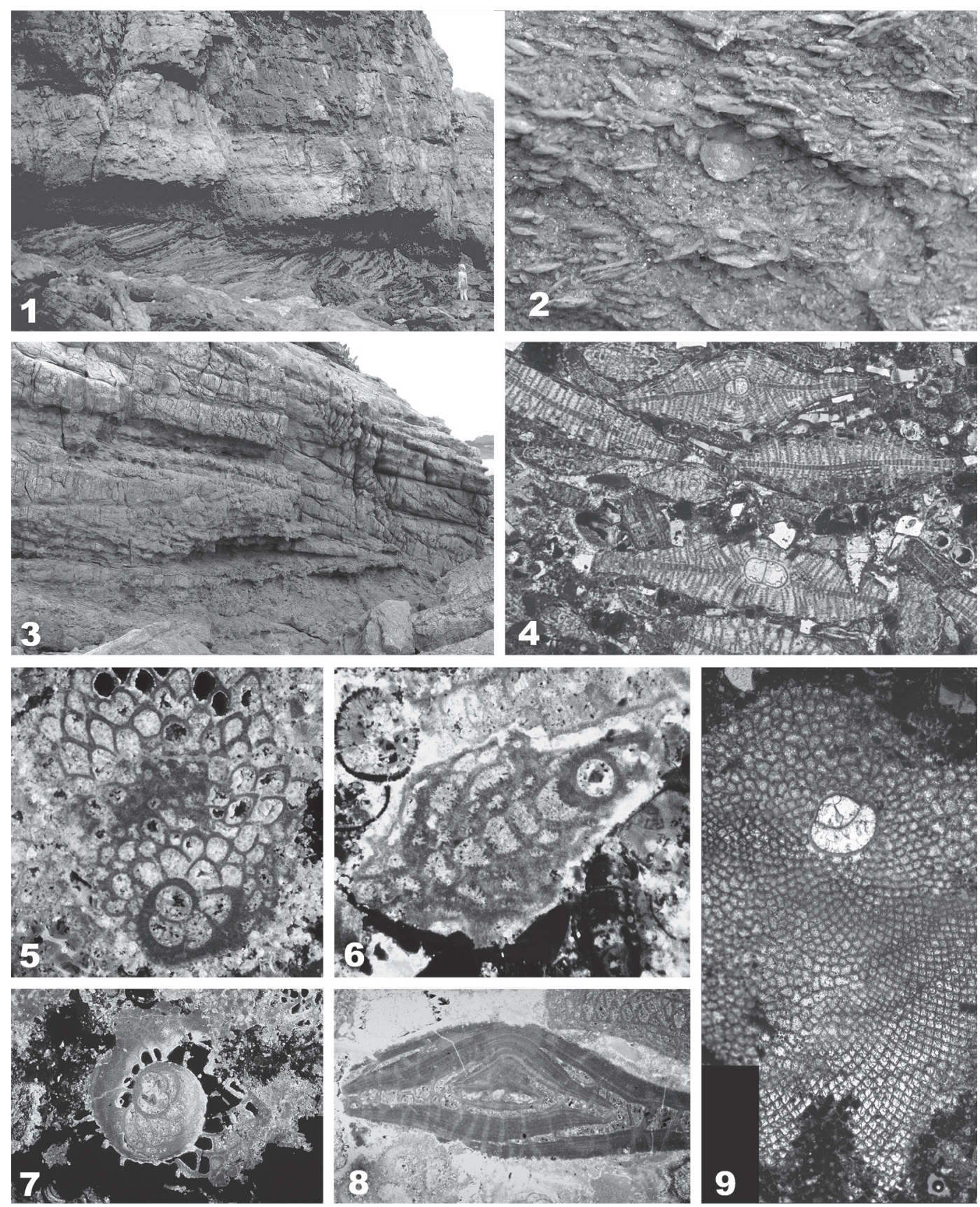


\section{Plate 1}

1. Upper Oligocene shallow water limestones rest on an angular unconformity over PaleoceneEocene distal turbidites and siliceous shales, Punta Peladas (Nosara, Costa Rica).

2. Bioclastic limestones packed with larger foraminifera mostly representing microspherical forms of Lepidocyclina sp. Width of image is $4.7 \mathrm{~cm}$.

3. Bioclastic limestones at Punta Peladas, Nosara ( $9^{\circ} 56^{\prime} 57^{\prime \prime}$ N, 85 $\left.45^{\circ} 40.60^{\prime \prime} \mathrm{W}\right)$. Successive sets of high angle foresets at various scales indicate a high energy, near shore carbonate bank environment.

4. Microfacies with Lepidocyclina yurnagurensis Cushman, Lepidocyclina vaughani Cushman and Miogypsina sp. Width of image is $800 \mu \mathrm{m}$.

5. Aequatorial section of Miogypsina tani Drooger. This cathodoluminescence (CL) micrograph allows to observe the real size of the protoconch and the shape of the nepionic stage, see Fig. 4. Width of image is $250 \mu \mathrm{m}$.

6. Vertical section of Miogypsina tani Drooger. This CL image shows the apical position of the embryon. Width of image is $250 \mu \mathrm{m}$.

7. Aequatorial section of Heterostegina antillea Cushman under CL showing a big protoconch followed by one kidney-shaped chamber typical for the Oligocene-Miocene American Heterostegina. Width of image is $250 \mu \mathrm{m}$.

8. Axial-oblique section of Heterostegina antillea Cushman. Width of image is $500 \mu \mathrm{m}$.

9. Aequatorial section of Lepidocyclina (Nephrolepidina) vaughani Cushman. View in transmitted light. Width of image is $300 \mu \mathrm{m}$. 

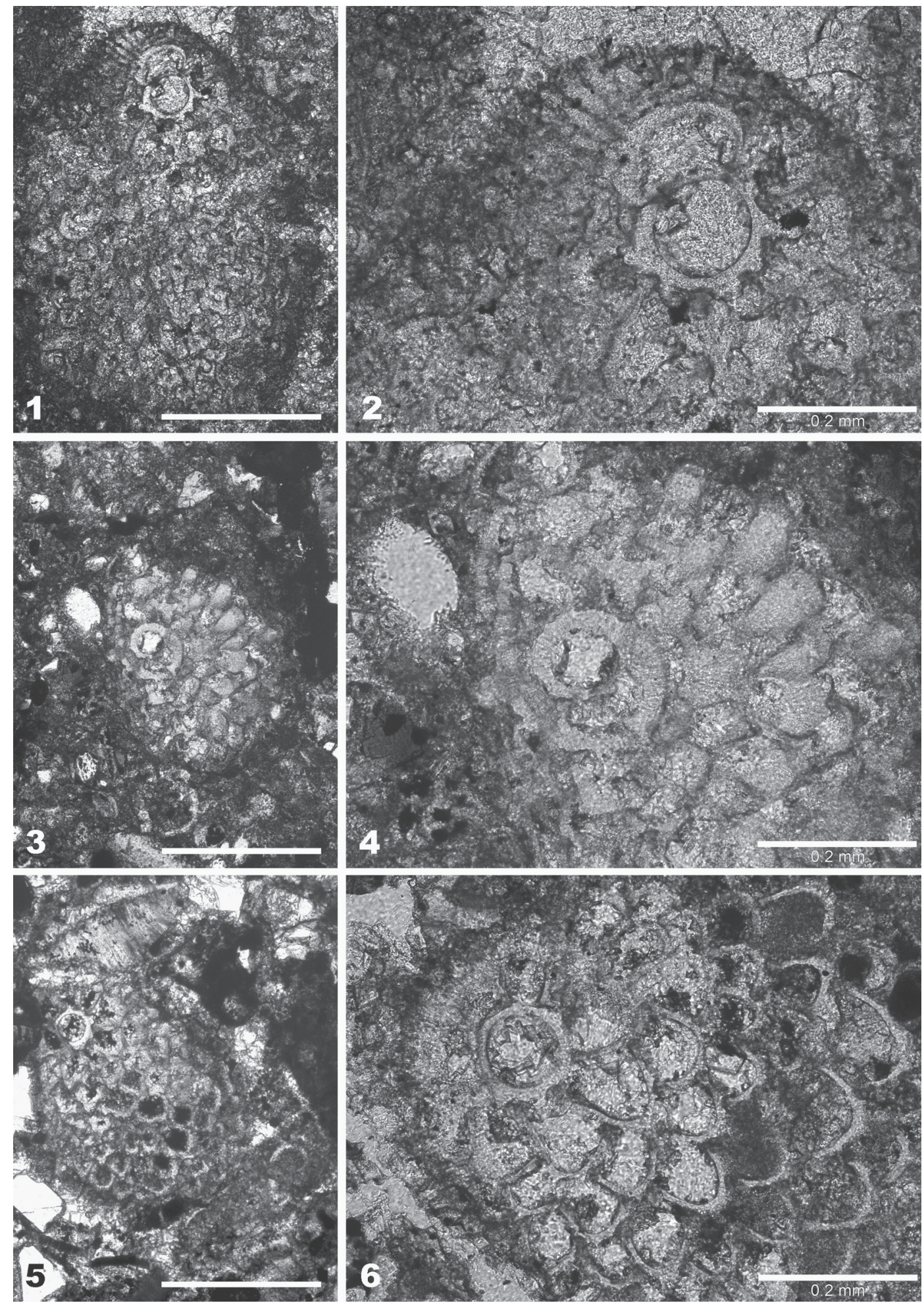


\section{Plate 2}

Transmitted light micrographs of thin sections of sample CM 1121, Punta Peladas, Nosara, Costa Rica.

1-2. Aequatorial section of Miogypsina tani Drooger showing a coarse marginal fringe in the apex of the test. Scale bars are $500 \mu \mathrm{m}$ in 1 , and $200 \mu \mathrm{m}$ in 2 .

3-4. Aequatorial section of Miogypsina gunteri Drooger showing a coarse recrystallized spiral coil. Scales bars are $500 \mu \mathrm{m}$ in 3 , and $200 \mu \mathrm{m}$ in 2 .

5-6. Aequatorial sections of Miogypsina tani Drooger, showing a specimen slightly conical, with de deuteroconch in the apex of test. Scales bars are $500 \mu \mathrm{m}$ in 5, and $200 \mu \mathrm{m}$ in 6 . 